\title{
Morphological Characterization and Pathogenicity of pythium sp. Infecting Cucumber Seedlings in Greenhouses
}

\author{
Mohamed M. Gharieb ${ }^{1}$, Gaber A. Abo-Zaid ${ }^{2}$, Shimaa I. Bashir ${ }^{3}$, Elsayed E. Hafez ${ }^{3}$
}

\begin{abstract}
Greenhouse-grown cucumber seedlings exhibiting typical symptoms of Pythium damping-off and root rot were collected. The causal agents were isolate on Pythium selective medium; nystatin, ampicillin, rifampicin, and miconazole (NARM) in potato dextrose agar (PDA). Four different isolates was isolated and their pathogenicity was tested using cotyledon and young seedlings assays. Results of these isolates showed variation in their ability to infect cucumber seedling. Isolate "GZ-11" was highly pathogenic, caused $100 \%$ pre- and post-emergence damping-off. The isolate was identified to the species level based on morphological characters along with sequences of the internal transcribed spacer (ITS) of the ribosomal DNA and showed $99 \%$ similarity to Pythium spinosum (Synonym of Globisporangium spinosum). Aggressiveness of $P$. spinosum was investigated at two levels of inoculum concentrations (10 and $20 \mathrm{~g} / \mathrm{kg}$ soil). Results reported that $P$. spinosum was highly aggressive and significantly reduced cucumber seed germination compared to the control.
\end{abstract}

Keywords: Pythium, pathogenicity, cucumber, ITS and phylogenetic tree

\section{INTRODUCTION}

Cucumbers (Cucumis sativus) are one of the most economically important crops worldwide and can be grown under greenhouse and filed condition (Davis et al. 2008). The total production of cucumber in Egypt 2018 was 457,795 tones (FAO, 2018). Cucumbers are affected by several diseases such as root rot (Chatterton and Punja, 2009), Fusarium wilt (Zhao et al. 2012), Pythium damping-off, Rhizoctonia damping-off (Kazerooni et al, 2019), downy mildew and powdery mildew (Wang et al. 2008). Damping-off and root rot are one of the most common disease affecting cucumber production.

Pythium is the major causal organism of this disease, especially under high humidity and cold conditions (McCarty and Miller, 2002). Most species of them have a wide range of hosts but some are restricted to certain family members causing reduction in crop yield.

DOI: 10.21608/ASEJAIQJSAE.2020.84490

${ }^{1}$ Botany Department, Faculty of Science, Menoufia University, Egypt.

${ }^{2}$ Bioprocess Development Department, Genetic Engineering and

Biotechnology Research Institute, City of Scientific Research and

Technological Applications, New Borg El-Arab City, 21934, Egypt.

${ }^{3}$ Plant Protection and Biomolecular Diagnosis Department, Arid Lands

Cultivation Research Institute, City of Scientific Research and

Technological Applications, New Borg El-Arab City, 21934, Egypt.

Coresponding author: y_basher@yahoo.com

Received February25, 2020, Accepted March27, 2020
Pythium attacks embryo, hypocotyl, and emerging radicle causing pre- and post-emergence damping-off disease. Roots of mature plant are also infected limiting plant growth and sometimes causing death (Schroeder et al. 2013). Shoot and root dry weights of cucumber plant were significantly decreased by Pythium utimum infection (Ravnskov et al. 2020). Several Pythium species can infect cucumber seedling including Pythium aphanidermatum, $P$. ultimum, $P$. deliense, $P$. myriotylum, and P. spinosum (Paul et al. 1996; Wulff et al. 1998; Roberts et al. 2007; Al-Balushi et al. 2018).

Identification of the Pythium species is based on the growth rate and morphological features on specific media, such as shape of sporangia, oogonia, and antheridia (Van der Plaats-Niterink, 1981). This requires high experience and a new techniques have been developed to facilitate and more accurate identification. Recently, several molecular tools including Speciesspecific molecular primers, Polymerase Chain Reaction (PCR) and the sequence of the ras-related protein gene have been developed (Moorman et al. 2002; Godfrey et al. 2003; Klemsdal et al. 2008)

The goal of this study was (i) to isolate and identify Pythium spp. associated with cucumber damping-off based on morphological features and molecular characterize. (ii) Screening pathogenicity of the Pythium isolate and (iii) Study the influence of inoculum density on disease severity on cucumber seedling.

\section{MATERIALS AND METHODS}

\section{Sample collection and Pythium isolation}

Infected cucumber seedlings were collected from greenhouses and open fields (Menoufia and Giza government, January 2017). The samples were washed under running tap water to remove soil debris and sterilized sequentially with $3 \% \quad(\mathrm{v} / \mathrm{v})$ sodium hypochlorite $(\mathrm{NaOCl})$ for $3-5 \mathrm{~min}, 70 \%(\mathrm{v} / \mathrm{v})$ ethanol for $1 \mathrm{~min}$ and then transferred to sterile distilled water for $3 \mathrm{~min}$. The crown and root were cut into fragments (0.5-1 cm long each) and placed on potato dextrose agar (PDA) plates supplemented with nystatin $(10 \mu \mathrm{g} / \mathrm{ml})$, 
ampicillin $(200 \mu \mathrm{g} / \mathrm{ml})$, rifampicin $(10 \mu \mathrm{g} / \mathrm{ml})$ and miconazole $(1 \mu \mathrm{g} / \mathrm{ml})$ as an antibacterial (Morita and Tojo, 2007). The plates were incubated at $25^{\circ} \mathrm{C}$ till pathogen growth was observed on the samples. Pythium spp. were morphologically identified according to the typical morphological features using light microscopy (GIPPON, GLCD-120, JAPAN) and hyphal tipped to obtain pure cultures.

\section{Pathogenicity test}

Petri dish test: Pre-emergence damping-off was tested in petri plates. Cucumber seeds (HAYEL, Hybrid cucumber) were surface sterilized as mentioned before. Seeds were germinated on moist, sterile filter paper for 2 days before being used. Ten seeds were placed in a 9 $\mathrm{cm}$ petri plate containing $1 \%(\mathrm{w} / \mathrm{v})$ water agar medium. For each Pythium isolate, one plug was inoculated to each plate and incubated at $25^{\circ} \mathrm{C}$ for seven days. Seeds were placed on non-inoculated plate as a control.

Pots test: All Pythium isolates were tested for pathogenicity (Post-emergence) on cucumber seedling at the 2-true leaf stage as described by Feng and Dernoeden (1999) with some modification. Plastic cups of $7 \mathrm{~cm}$ diameter, with drainage holes, were filled with autoclaved 2:1 (v/v) sand-peat mixture and one seedling was transplanted per cup. After two days, two mycelium plugs ( $7 \mathrm{~mm}$ in diameter) taken from the edge of 5-days old culture were placed around the base of each seedling and covered with a thin layer of soil. Agar plugs were applied to control cups. Seedlings were incubated at $25^{\circ} \mathrm{C}$ in growth chamber with $12 \mathrm{~h} /$ day of fluorescent light and irrigated every 2 days with sterile distilled water. For each treatment, there were four randomly arranged replicates. The percentages of post-emergence damping-off were recorded for two weeks after transplanting.

\section{Effect of Pythium density on disease severity}

Pythium inoculum was prepared by growing three plugs on sterilized corn-sand medium, which contained corn seeds, sand and deionized water at the ratio 1:1:2 (V/V/V) respectively, for 10 days at $25^{\circ} \mathrm{C}$. The inoculum was then mixed with sterilized clay soil at a rate of 10 and $20 \mathrm{~g} / \mathrm{kg}$ soil. Plastic pots $(500-\mathrm{ml})$ were filled with the infested soil and planted with five surface-sterilized seeds. Negative control was established by planting seeds in non-infested soil. Pots were watered manually to maintain soil moisture. Three replicates were prepared for each treatment and the experiment was repeated twice. Pre-damping off was calculated, after three weeks of planting, by comparing the emergence percentage with that in control.

\section{Statistical analysis}

All experiments were carried out twice in triplicate and the obtained data were analyzed by analysis of variance (ANOVA) using the Wasp version 2.0. The Critical Difference $(\mathrm{CD})$ at $\mathrm{P}=0.05$ was used to compare the means controls against the rest of the treatments. Oomycetes identification using Internal transcribed spacer (ITS) region

Genomic DNA was extracted according to CTAB method as described by Doyle et al., (1987). The ITS region was amplified using primers ITS1 (5'-TCT GTA GGT GAA CCT GCG G-3') and ITS4 (5'-TCC TCC GCT TAT TGA TAT GC-3'). The reaction mixture $(25 \mu \mathrm{l})$ contained $5 \mu \mathrm{l}$ of $\mathrm{Taq}$ red buffer, $20 \mathrm{ng}$ of template DNA, 10 pmol of each primers, $0.25 \mathrm{U}$ of Taq polymerase (Bioline, UK). PCR cycling conditions were: $95^{\circ} \mathrm{C}$ for $2 \mathrm{~min}, 30$ cycles of $95^{\circ} \mathrm{C}$ for $1 \mathrm{~min}$; $50^{\circ} \mathrm{C}$ for $1 \mathrm{~min} ; 72^{\circ} \mathrm{C}$ for $1 \mathrm{~min} ; 1$ cycle of $72^{\circ} \mathrm{C}$ for 5 min. The PCR product was checked on $1.5 \%$ agarose gel stained with $0.05 \mu \mathrm{g} / \mathrm{ml}$ ethidium bromide and the target band was purified using the GF-1 PCR clean-up kit (Vivantis Technologies, Sdn. Bhd.) according to the manufacturer's instructions.

\section{Sequence analysis}

The purified PCR product was sequenced and data obtained were compared with those in GenBank database of National Center for Biotechnology Information (http://bast.ncbi.nlm.nih.gov/Blast.cgi) using the BLAST algorithm. Phylogenetic analysis was performed using MEGA version $\mathrm{X}$ version 10.0.5 (https://www.megasoftware.net/).

\section{RESULTS AND DISCUSSION}

\section{Pathogenicity of Pythium spp.}

Four Pythium spp. were isolated from the diseased plant during winter 2017. The tested isolates showed a wide range in their pathogenicity (Table 1). Two isolates (MF-7 and MF-15) were either nonpathogenic or have low level of pathogenicity to cucumber seedling. The isolate MF-22 was moderately pathogenic and cause pre- and post-emergent damping of at the rate $79 \%$ and $50 \%$ respectively. Among the tested isolates, GZ-11 isolate was found to be the highest pathogenic, causing seed rot and seedling damping-off at rate $100 \%$, and selected to be identified. Wei et al. (2011) in study with eight Pythium spp reported that Pythium ultimum was the most pathogenic species resulting in $97 \%$ seed rot and $46.4 \%$ damping-off on soybean. Rossman et al (2017) observed variations in the virulence of the Pythium isolates in causing seed rot and pre-emergence damping-off of dry bean. 
Table 1. Effect of Pythium isolates on seed germination and seedling healthy. Significant differences $(p<0.05)$ between means were followed by different letters

\begin{tabular}{cccc}
$\begin{array}{c}\text { Isolate } \\
\text { code }\end{array}$ & Location & $\begin{array}{c}\text { Seed } \\
\text { germination } \\
(\boldsymbol{\%})\end{array}$ & $\begin{array}{c}\text { Healthy } \\
\text { seedling } \\
(\boldsymbol{\%})\end{array}$ \\
\hline MF-7 & Menoufia & $100^{\mathrm{a}}$ & $75^{\mathrm{a}}$ \\
MF-15 & Menoufia & $100^{\mathrm{a}}$ & $100^{\mathrm{a}}$ \\
GZ-11 & Giza & $0.0^{\mathrm{c}}$ & $0.0^{\mathrm{b}}$ \\
MF-22 & Menoufia & $76.6^{\mathrm{b}}$ & $50^{\mathrm{ab}}$ \\
$\mathrm{CD}(P=$ & & 8.04 & 0.588 \\
$0.05)$ & & 6.12 & 67.89 \\
$\mathrm{CV}(\%)$ & & & \\
\hline
\end{tabular}

\section{Morphological and identification of Pythium sp.}

Morphological characterization of the selected isolate (GZ-11) was similar to Pythium spinosum (Figure 1). Colonies grew rapidly, daily growth rate 30 $35 \mathrm{~mm}$, on PDA medium at $25^{\circ} \mathrm{C}$ with white, dense aerial mycelium. Main hyphae was $2-5 \mu \mathrm{m}$ wide (av. $3.7 \mu \mathrm{m}$ ) with occasionally varying numbers of blunt, finger-like projections. Sporangia and zoospore not formed. Oogonia were globose or fusiform, intercalary or terminal, 15-24 $\mu \mathrm{m}$ (av. $19 \mu \mathrm{m}$ ) diameter, mostly smooth but occasionally with blunt protuberances. Antheridia were typically monoclinous, 1 per oogonium. Oospore plerotic, 15-22 $\mu \mathrm{m}$ (av. $18 \mu \mathrm{m}$ ) diameters, thin-walled (av. $1.3 \mu \mathrm{m}$ ).

\section{Molecular characterization of Pythium spinosum}

Genomic DNA of Pythium isolate was extracted and the ITS rDNA region (ITS1-5.8S-ITS2) was amplified by PCR (Figure 2). After visualization of the PCR product on $1.5 \%$ agarose gel, a specific DNA band was shown at the length of $1000 \mathrm{bp}$. The oomycetes identification was confirmed by sequence comparison of the ITS region with sequences obtained from the Nucleotide Database of (NCBI). The sequence of Pythium isolate (GZ-11) was closely related with that of Globisporangium spinosum MK910133 (Basionym: Pythium spinosum) with 99\% similarity (Figure 3).

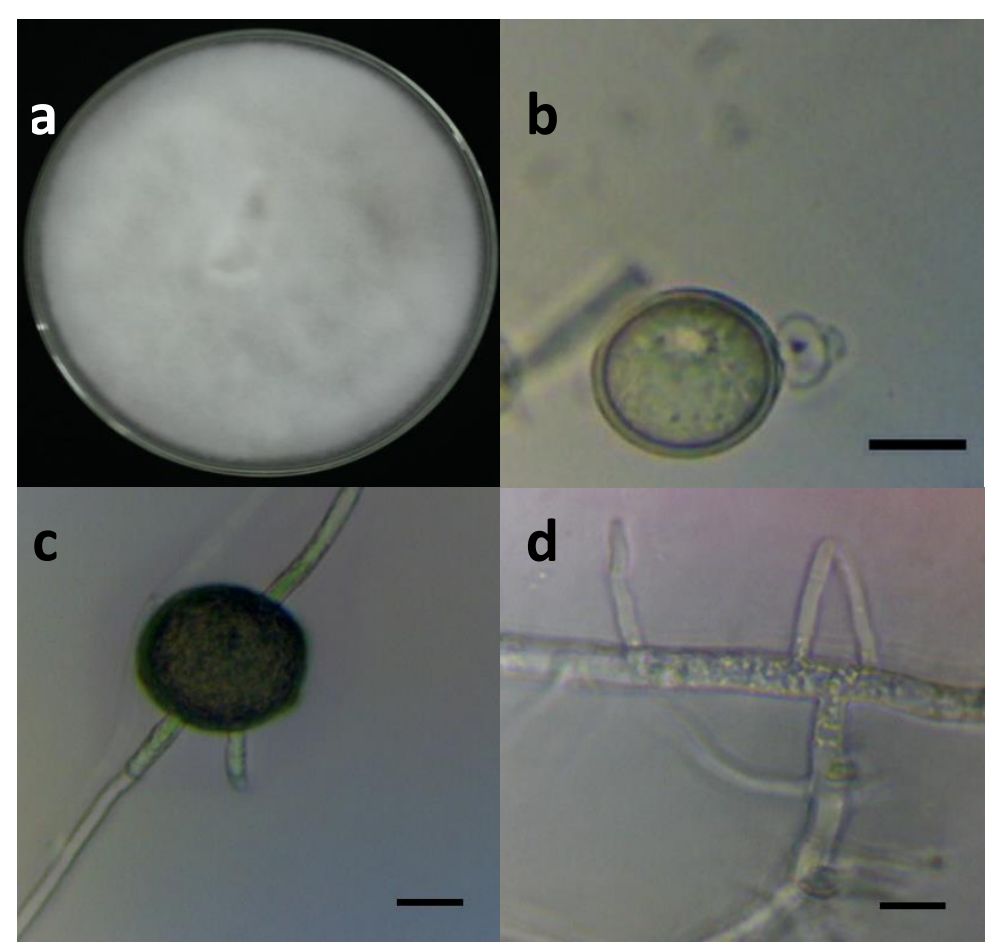

Fig. 1. Morphology of Pythium spinosum. (a) Colony patterns at $25^{\circ} \mathrm{C}$ on PDA, (b) Monoclinous antheridium attached to a oogonium, (c) intercalary oogonium with a projection, (d) hyphae with spine-like projections. Scale bars $=10 \mu \mathrm{m}$ 


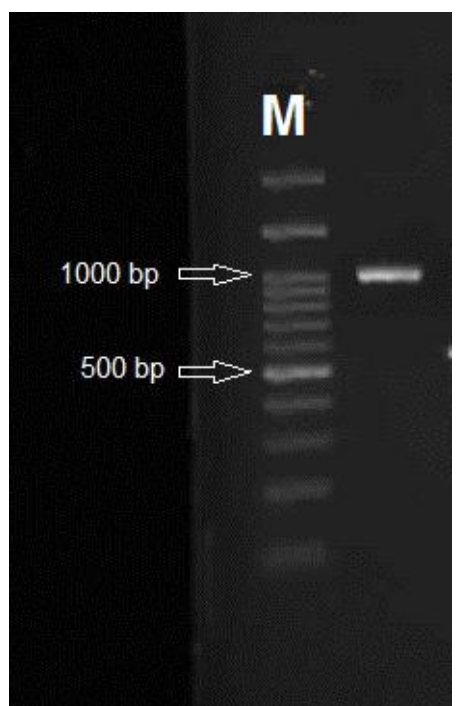

Fig. 2. Electrophoresis of the PCR product of ITS rDNA of Pythium spinosum on $1.5 \%$ agarose gel (lane M: 1.5 Kb DNA Marker)

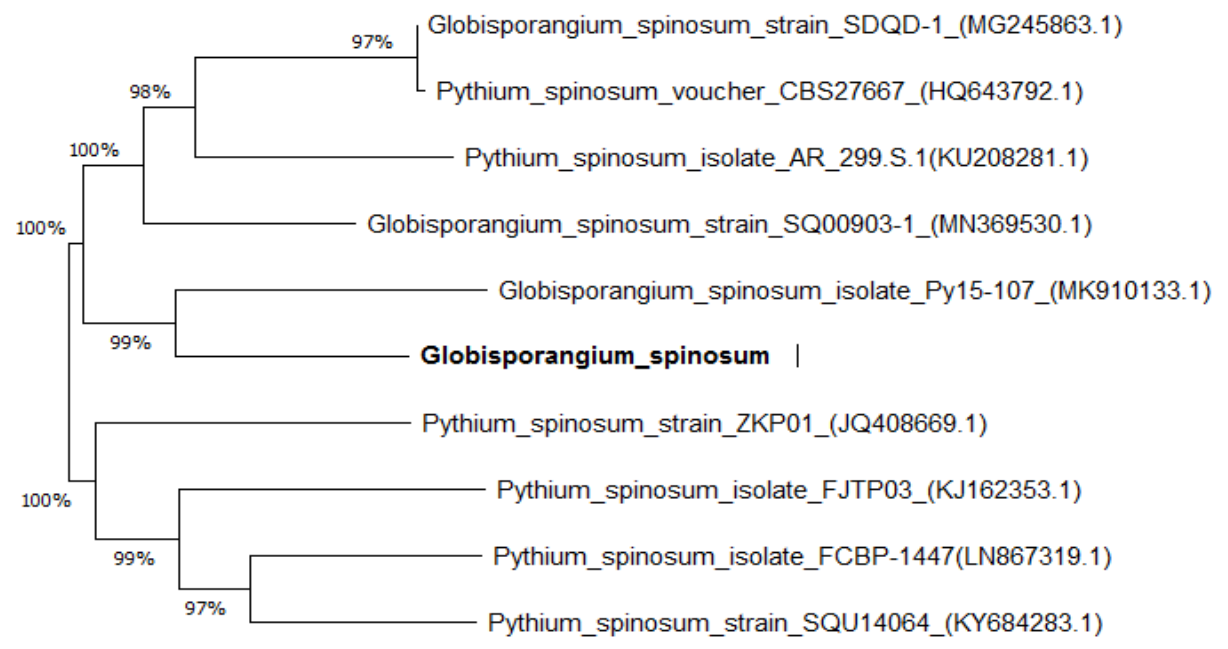

Fig. 3. Unrooted Phylogenetic tree showing the position of $P$. spinosum isolate based on internal transcribed spacer (ITS) sequence of nuclear rDNA 


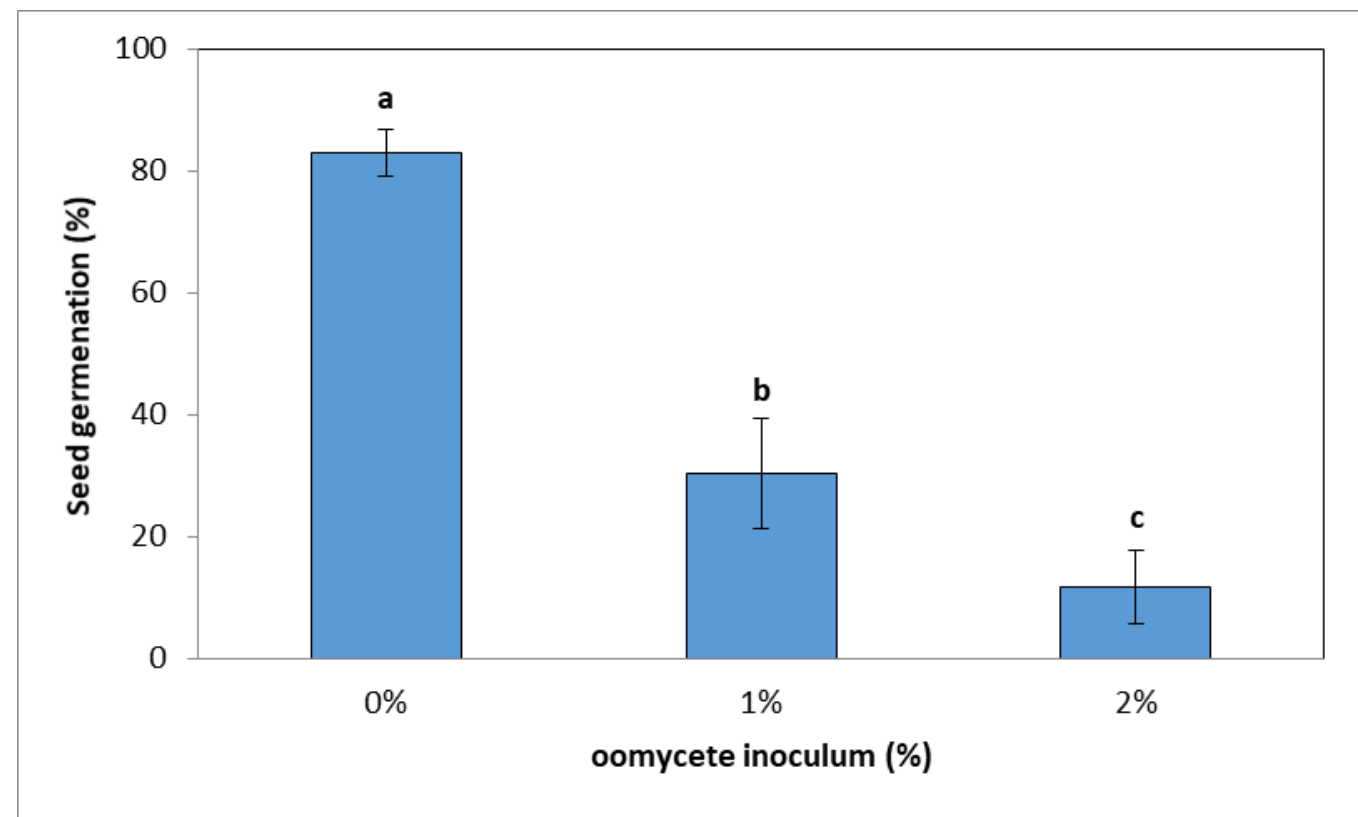

Fig. 4. Effects of Pythium spinosum inoculum concentrations on cucumber seed germination. Vertical bar represent standard error

\section{Influence of inoculum density on severity of damping-off disease}

The seed germination percentage was significantly $(p<0.001)$ influenced by the inoculum concentrations in the soil (Figure 4). Within three weeks, P. spinosum isolate was found to exhibit high level of aggressiveness, even at inoculum densities as small as $10 \mathrm{~g} / \mathrm{kg}$ soil, as compared to the control.

The result also showed that disease severity was directly proportional to the oomycete inoculum size. Our results were similar to Hwang et al. (2001) who found that the survival of pea seedling decrease as inoculum concentration of $P$. irregulare and $P$. ultimum increased. Development of Pythium Stunt disease on lettuce was enhanced by increasing soil inoculum density of $P$. tracheiphilum (Sauvageau et al. 2019).

\section{Conflict of interest}

The author(s)they do not have any conflict of interest

\section{REFERENCES}

Al-Balushi, Z.M., H. Agrama, I.H. Al-Mahmooli, S.S.N. Maharachchikumbura and A.M. Al-Sadi. 2018. Development of Resistance to Hymexazol among Pythium Species in Cucumber Greenhouses in Oman. Plant Dis. 102(1): 202-208.
Chatterton, S. and Z.K. Punja. 2009. Interactions between Clonostachys rosea f. catenulata, Fusarium oxysporum and Cucumber Roots Leading to Biological Control of Fusarium Root and Stem Rot. In book: Recent Developments in Management of Plant Diseases. 93-106.

Davis, A.R., P. Perkins-Veazie, Y. Sakata, S. López-Galarza, J.V. Maroto, S.G. Lee, Y.C. Huh, Z. Sun, A. Miguel, S.R. King, R. Cohen and J.M. Lee. 2008. Cucurbit grafting. Crit. Rev. Plant Sci. 27:50-74.

FAO. 2018. Faostat database available from http://faostat:fao.org. Accessed date.

Feng, Y. and P. H. Dernoeden. 1999. Pythium Species Associated with Root Dysfunction of Creeping Bentgrass in Maryland. Plant Dis., 83:516-520.

Godfrey S.A.C., R.D. Monds, D.T. Lash and J.W. Marshall. 2003. Identification of Pythium oligandrum using speciesspecific ITS rDNA PCR oligonucleotides. Mycol. Res. 107:790-796.

Hwang, S.F., B.D. Gossen, K.F. Chang, G.D. Turnbull and R.J. Howard. 2001. Effect of seed damage and metalaxyl seed treatment on pythium seedling blight and seed yield of field pea. Can. J. Plant Sci. 81: 509-519.

Kazerooni, E.A., V. Rethinasamy and A.M. Al-Sadi. 2019. Talaromyces pinophilus inhibits Pythium and Rhizoctoniainduced damping-off of cucumber. J. Plant Pathol. 101:377-383.

Klemsdal, S.S., M.L. Herrero, L.A. Wanner, G. Lund and A. Hermansen. 2008. PCR based identification of Pythium spp. causing cavity spot in carrots and sensitive detection in soil samples. Plant Pathol. 57:877-886. 
McCarty, L.B. and G. Miller. 2002. Managing Bermudagrass Turf: Selection, Construction, Cultural Practices, and Pest Management Strategies. Sleeping Bear Press, Chelsea, MI.

Moorman, G.W., S. Kang, D.M. Geiser and S.H. Kim. 2002. Identification and characterization of Pythium species associated with greenhouse floral crops in Pennsylvania. Plant Dis. 86:1227-31.

Morita, Y. and M. Tojo. 2007. Modifications of PARP medium using fluazinam, miconazole, and nystatin for detection of Pythium spp. in soil. Plant Dis. 91:1591-1599.

Paul, B., D. Bazireau and G. Gambade. 1996. Pythium deliense causing severe damping-off of cucumber seedlings and its biological control by soil bacteria. Microbiological Research. 151(3): 309-312.

Ravnskova, S., C. Cabrala and J. Larsenb. 2020. Mycorrhiza induced tolerance in Cucumis sativus against root rot caused by Pythium ultimum depends on fungal species in the arbuscular mycorrhizal symbiosis. Biol control. 141:104133.

Roberts, D.P., L.F. McKenna, D.K. Lakshman, S.L.F. Meyer, H. Kong, J.T. de Souza, J. Lydon, C.J. Baker, J.S. Buyer and S. Chung. 2007. Suppression of damping-off of cucumber caused by Pythium ultimum with live cells and extracts of Serratia marcescens N4-5. Soil Biol. and Biochem. 39(9):2275-2288.

Rossman, D.R., A. Rojas, J.L. Jacobs, C. Mukankusi, J.D. Kelly and M.I. Chilvers. 2017. Pathogenicity and Virulence of Soilborne Oomycetes on Phaseolus vulgaris. Plant Dis. 101(11):1851-1859.
Sauvageau, A., V. Gravel and H.V. Heyden. 2019. Soilborne Inoculum Density and Environmental Parameters Influence the Development of Pythium Stunt Caused by Pythium tracheiphilum in Head Lettuce Crops. Plant Dis. 103(7): 1685-1692.

Schroeder, K.L., F.N. Martin, A.W.A.M. de Cock, C.A. Lévesque, C.F.J. Spies, P.A. Okubara and T.C. Paulitz. 2013. Molecular Detection and Quantification of Pythium Species: Evolving Taxonomy, New Tools, and Challenges. Plant Dis. 97(1):4-20.

van der Plaats-Niterink, A.J.V. 1981. Monograph of the genus Pythium. Stud. Mycol. 21:1-242.

Wang, N., Y. Ma, C. Yang, G. Dai and Z. Wang. 2008. rDNAITS sequence analysis of pathogens of cucumber downy mildew and cucumber powdery mildew. Front. Agric. China. 2(3):317-320.

Wei, L., A.G. Xue, E.R. Cober, C. Babcock, J.X. Zhang, S.Z. Zhang, W.B. Li, J.J. Wu and L.J. Liu. 2011. Pathogenicity of Pythium species causing seed rot and damping-off on soybean under controlled conditions. Phytoprotection. 91: 3-10.

Wulff, E.G., A.T.H. Pham, M. Chérif, P. Rey, Y. Tirilly and J. Hockenhull. 1998. Inoculation of cucumber roots with zoospores of mycoparasitic and plant pathogenic Pythium species: Differential zoospore accumulation, colonization ability and plant growth response. Eur. J. Plant Pathol. 104(1): 69-76.

Zhao, S., C.M. Du and C.Y. Tian. 2012. Suppression of Fusarium oxysporum and induced resistance of plants involved in the biocontrol of Cucumber Fusarium Wilt by Streptomyces bikiniensis HD-087. World J. Microbiol. Biotechnol. 28(9):2919-2927.

\section{الملخص العربي}

\section{الخصائص المورفولوجية والقدرة الإمراضية لبيثيوم يصيب بادرات الخيار في الصوب الزراعية} محمد مدحت غريب, جابر أبو زيد, شيماء بشير و السيد السيد حافظ

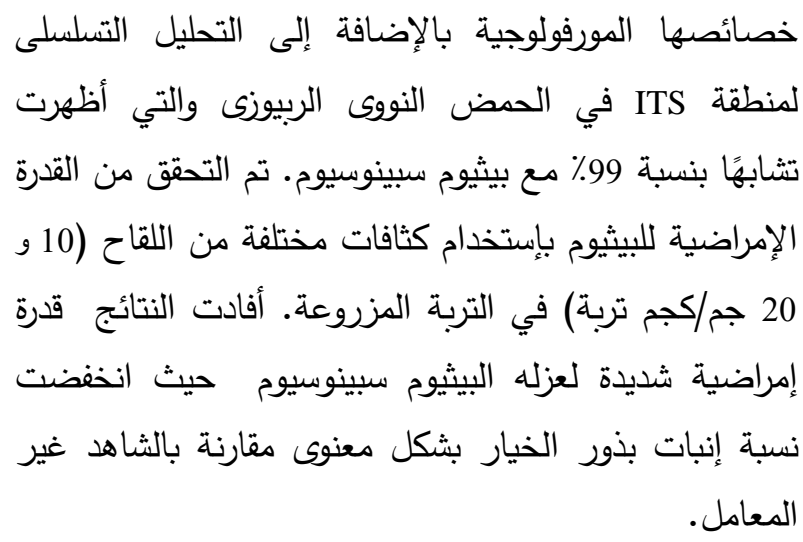

جُمعت عينات لنباتات خيار تظهر عليها أعراض مرض موت البادرات وعفن الجذورن داخل صوب زراعية، حيث تم عزل المسبب المرضي على وسط إنتخابي للبيثيوم يتكون من بيئة PDA مضاف إليها نيستاتين وأمبيسلين و ريفامبيسين و ميكونازول (NARM). عُزلت أربعة أنواع مختلفة من البيثيوم وأُختبرت قدرتها الإمراضية على بادرات لنبات الخيار (هجين هايل). أظهرت العزلات تبايناً في قدرتها على الإصابة. تسببت العزلة GZ-11 فى إحداث أعلى نسبة إصابة 100٪ للبادرات قبل وبعد الإنبات. عُرفت العزلة بالإعتماد علي 